\author{
KATARZYNA BURSKA* \\ Uniwersytet Łódzki, Wydział Filologiczny, \\ Instytut Filologii Polskiej, Katedra Współczesnego Języka Polskiego
}

\title{
Analityczne konstrukcje czasownikowe w polskich tygodnikach
}

Dziennikarze od lat stawiają sobie pytania: Jak wyrazić swoje myśli, by zostać właściwie zrozumianym przez odbiorcę? Jakich słów użyć, aby czytelnik prawidłowo odczytał przesłanie tekstu? A może lepiej nie mówić wszystkiego wprost, tylko enigmatycznie przedstawić swoje zdanie i pozostawić adresatowi możliwość swobodnej interpretacji? Istnieje szereg środków wyrazu, które pozwalają przekazać te same czy podobne treści z wykorzystaniem różnego doboru słownictwa.

W niniejszym opracowaniu szczegółowemu oglądowi zostaną poddane różne sposoby tworzenia analitycznych konstrukcji czasownikowych mających syntetyczne odpowiedniki. Jako podstawa badawcza posłużą jednostki leksykalne pochodzące z „Polityki” i „Piłki Nożnej” - dwóch polskich tygodników o odmiennej tematyce - z wybranych numerów z 2012 roku. Z jakich komponentów budowane są omawiane struktury? W jakim celu są wykorzystywane w artykułach publikowanych w polskich periodykach? Jakie relacje zachodzą między wielowyrazowymi czasownikami a ich jednoelementowymi ekwiwalentami?

W dotychczasowych pracach badawczych zajęto się przede wszystkim kolokacjami werbo-nominalnymi (zwanymi też zwrotami lub orzeczeniami peryfrastycznymi, multiwerbizmami, analitycznymi czasownikami funkcjonalnymi, konstrukcjami lub strukturami analitycznymi), czyli połączeniami składającymi się z czasownika i rzeczownika abstrakcyjnego. Jak podkreśla Grażyna Vetulani, choć są to formy złożone, to trzeba je uznać za wykładniki jednego pojęcia. „W konstrukcjach tych cechy morfologiczne wiążą się z czasownikiem [...], a cechy semantyczne - z rzeczownikiem" [Vetulani 2001: 59]. Janusz Anusiewicz, definiując konstrukcje analityczne, stwierdził, że są to

* Autorka jest laureatką III edycji nagrody naukowej Fundacji UŁ za szczególne osiągnięcia naukowe w latach 2012-2013 w obszarze nauk humanistycznych w grupie uczestników studiów doktoranckich UŁ. 
takie niewspółrzędne związki wyrazowe, które współistnieją obok znaczeniowo im ekwiwalentnych prostych (jednordzeniowych) wyrazów, przy czym morfem leksykalny wyrazu podrzędnego wchodzącego w skład danej konstrukcji jest tożsamy substancjalnie z morfemem leksykalnym wchodzącym w skład odpowiadającej jej formy prostej wyrazu. [Anusiewicz 1978: 22]

Substancjalna tożsamość - jako za bardzo ograniczająca - została odrzucona przez kolejnych badaczy, m.in. Wacława Cockiewicza [2000: 143-153] czy Iwonę Loewe [2010: 177-188]. Niniejsze opracowanie także pozwala spojrzeć na omawiane zjawisko z szerszej perspektywy - jako analityczne konstrukcje czasownikowe traktuje się nie tylko te, które zawierają wspólne morfemy z odpowiadającymi im syntetyzmami leksykalnymi, ale także wszelkie wielowyrazowe określenia posiadające jednowyrazowy odpowiednik tożsamy lub bliski znaczeniowo, w tym związki frazeologiczne, które da się zastąpić syntetycznym czasownikiem. Takie ujęcie pozwala wpisać wieloskładnikowe konstrukcje czasownikowe i ich ekwiwalenty w szeroko pojmowane analityzmy leksykalne mające jednoelementowe odpowiedniki [por. Cockiewicz 2000].

$\mathrm{W}$ analizowanym materiale badawczym odnotowano struktury werbo-nominalne, w których widoczne jest pokrewieństwo morfologiczne z jednoelementowym czasownikiem im odpowiadającym. Chętnie wykorzystuje się bezokolicznik mieć, który jest łączony z rzeczownikami bądź wyrażeniami przyimkowymi zamiast pamiętać, wptywać czy myśleć w tekstach prasowych pojawiają się mieć w pamięci, mieć wptyw, mieć na myśli . Wydaje się, że wielowyrazowe sformułowania mają lekko patetyczny wydźwięk:

Postawiono na Zahouiego, mając w pamięci, że jedyny tytuł mistrza Afryki Słonie wywalczyły 20 lat temu pod wodzą właśnie krajowego szkoleniowca Martiala Yeo. (PN2012, 6, 4)

Ma bardzo dobrych zawodników, ma w pamięci świeży sukces, którym było wywalczenie Pucharu Polski z Michałem Probierzem na ławce, ma wreszcie prezesa, który ligowym piłkarzem był i choć nie osiągnął spektakularnych sukcesów w futbolu, na pewno zna zapach szatni. (PN2012, 10, 2)

Co prawda w minionej kolejce Lewy zszedł z boiska bez trafienia, a jego zmiennik - Lucas Barrios - zdobył gola, ale to nie powinno mieć żadnego wpływu na kształt rankingu napastników Juergena Kloppa. (PN2012, 6, 13)

- Bez kilku małych nieporozumień, które nie miały wpływu na wynik i przebieg meczu, wszystko było w porządku. (PN2012, 24, 29)

Kogoś ma pan konkretnie na myśli? (PN2012, 48, 15)

Kolejną charakterystyczną podstawę analitycznych konstrukcji czasownikowych stanowi dać. Szczególnie częste obecne jest połączenie dać (sobie) radę, które zastępuje analityczne poradzić (sobie). Obie formy są używane równie często w artykułach o różnorodnej tematyce, choć analityczne zestawienie ma bardziej potoczny charakter niż jego wielowyrazowy ekwiwalent:

Chęć udowodnienia samemu sobie, że jestem okej, dam radę, wszystko będzie grało. (P2012, $51-52,22)$

Oni nie dają sobie z tym rady. (P2012, 51-52, 84) 
Z dobrej strony w kilku ostatnich meczach pokazał się Rymaniak, doświadczony Broź powinien dać sobie radę w reprezentacyjnej próbie. (PN2012, 50, 42)

Najważniejsze dla nas Niemcy, jak dotąd jakoś sobie radzą. (P2012, 50, 45)

Tak samo jak za mało promują własną przedsiębiorczość i nie uczą radzić sobie z ewentualnymi niepowodzeniami. (P2012, 50, 51)

Jednak czy dosyć konserwatywny w podejściu do zawodników Benitez poradziłby sobie ze specyfiką szatni Chelsea? (PN2012, 11, 16)

Bezokolicznik dać bywa łączony także z innymi rzeczownikami, np. wyraz, sygnat czy radość. Mimo że wyrazić, zasygnalizować czy uradować niosą te same znaczenia, to peryfrastyczne określenia bardziej uwypuklają przekazywane treści. W przypadku dać sygnat i zasygnalizować istotną kwestią może być również ekonomia - dwuwyrazowa konstrukcja jest dłuższa tylko z pozoru, w rzeczywistości bowiem składa się z mniejszej liczby znaków niż pojedynczy czasownik, co - zwłaszcza w przypadku krótkich form dziennikarskich - może mieć znaczenie, np.

W 16 minucie meczu fani wstali i głośnymi oklaskami dali wyraz, że nadal mają wielki szacunek do Di Matteo. (PN2012, 48, 23)

Takie mecze i takie wyniki dają kibicom mnóstwo radości. (PN2012, 48, 39)

Poderwałem się natychmiast z ławki, a Franciszek Smuda dal sygnal, bym wchodził. (PN2012, $24,12)$

Zamiast skrytykować nierzadko używa się poddać krytyce, co dobitniej zaznacza opisaną postawę, np.

Arbitra meczu w Bielsku-Białej krytyce poddal Ireneusz Jeleń. (PN2012, 49, 10)

Co ciekawe, niemieckie media nie poddały zbyt ostrej krytyce drużyny z Leverkusen. (PN2012, 48, 34)

Podobne funkcje opisowej konstrukcji da się zaobserwować w połączeniu wywierać wpływ, zestawienie czasownika i rzeczownika uwypukla rangę piłkarza w drużynie:

Wywieral większy wpływ na grę swoich zespołów niż Lewy i dlatego wyprzedził go w walce o miejsce $\mathrm{w}$ jedenastce miesiąca. (PN2012, 49, 32)

Odwrotny zabieg ujawnia się w parze watpić - podawać w watpliwość, to druga - opisowa - konstrukcja ma silniejsze oddziaływanie, wyraża większą niepewność wobec podejmowanych działań:

Każde z tych trafień, a ostatnie szczególnie, potwierdzają, że w błędzie byli ci, którzy podawali w wątpliwość techniczną maestrię mierzącego 194 centymetry Ibrahimovicia. (PN2012, 48, 3) 
Powszechnym orzeczeniem peryfrastycznym stosowanym w nomenklaturze sportowej jest oddać strzał, które zastępuje syntetyczne strzelić. Co godne odnotowania, Stownik poprawnej polszczyzny pod red. Andrzeja Markowskiego uznaje połączenie oddać strzat do bramki za niepoprawne [SPP 2002: 985], dziennikarze sportowi używają go jednak tak często, że być może wkrótce zostanie ono zaakceptowane przez wydawnictwa normatywne:

To właśnie Cesc oddal pierwszy groźny strzal w drugiej części gry. (PN2012, 24, 31)

To fakt, ale z jednym, za to istotnym zastrzeżeniem - oprócz meczu z Włochami, w którym Kuba nie wykorzystał rzutu karnego, bardziej podając do Gianluigiego Buffona, niż oddając strzal. (PN2012, 6, 28)

Już w siódmej minucie po faulu Matysika Boy strzela z wolnego w okno. (PN2012, 6, 47)

Za pomocą analitycznych konstrukcji czasownikowych może być wyrażona podniosłość przekazywanych treści. Z taką sytuacją bez wątpienia spotykamy się w połączeniach: złożyć rezygnację, dokonywać selekcji, udzielać świadectw czy snuć porównania. Jednoelementowe zrezygnować, selekcjonować, świadczyć i porównać nie nadają przekazowi tak dużej patetyczności jak ich wieloczłonowe zastępniki:

Premier Mario Monti zdecydował, że natychmiast po przyjęciu przez parlament ważnej dla kraju ustawy stabilizacyjnej złoży rezygnację. (P2012, 50,7)

Dziennikarzom nawet się nie śniło, że to na nich spadnie teraz ciężar ochrony najbardziej strzeżonych tajemnic państwowych i że to oni będą musieli dokonywać selekcji, co można ujawnić, a co jednak powinno zostać ukryte. (P2012, 50, 10)

Gdy rodzice Glorii Wrony udzielają świadectw o jej cudownym uzdrowieniu, publiczność jest proszona o oklaski dla tego dziecka. (P2012, 50, 26)

Chyba nie ma sensu snuć porównań. (PN2012, 49, 9)

W ogóle da się w jakikolwiek sposób porównać tamtego Piasta z tym obecnym. (PN2012, 49, 9)

Nierzadkie jest także posługiwanie się komponentem prowadzić, by zbudować analityczne konstrukcje czasownikowe w miejsce obserwować czy remontować. O ile forma prowadzić obserwacje może być odczytywana neutralnie, o tyle pozorny patos obecny w sformułowaniu prowadzić remont $\mathrm{z}$ jednej strony budzi u odbiorcy śmieszność, wywołując skojarzenia z mało zrozumiałym stylem urzędowym, z drugiej jednak użycie takiego połączenia wydaje się uzasadnione - oba wymiennie stosowane orzeczenia pojawiły się w tym samym tekście, nadawcą kierowały zatem prawdopodobnie względy stylistyczne, chciał w ten sposób uniknąć powtórzenia:

Nie muszę do nikogo chodzić w tej sprawie, właściciel klubu ma wypracowaną długoletnią strategię budowy zespołu, nieustannie prowadzone są obserwacje kandydatów do gry w Lechu. (PN2012, 50, 14) 
- Prowadziliśmy intensywne remonty i renowacje. (PN2012, 24, 27)

Remontowaliśmy drogi, odświeżaliśmy centrum miasta - powiedział „Piłce Nożnej” Andrij Sadowy, mer Lwowa, który w trakcie trwania turnieju odgrywa rolę pierwszego gospodarza. (PN2012, 24, 27)

Dzięki dwuczłonowemu połączeniu dokonać zmian podkreślona została ranga czynności wykonywanych przez trenera, analityczne uzyskać przewage uwypukla zaś dominację drużyny chorwackiej na boisku:

Bułgar Nikołaj Kostow, zastępca Pawła Kuczerwowa, dokonal pewnych zmian w składzie, taktyce, ale na efekty musieliśmy poczekać. (PN2012, 48, 20)

Czy zatem grał pan kiedyś w takim meczu, gdzie trener dokonuje jednej tylko zmiany i jest to zmiana bramkarza? (PN2012, 24, 13)

On decyduje, w którym momencie zmienia zawodników. (PN2012, 24, 13)

Z upływem czasu Chorwaci, uzyskując przewagę liczebną, starali się jak najszybciej odbierać podopiecznym Trapa ochotę do gry, pozostawiając z tyłu trzech lub nawet tylko dwóch obrońców. (PN2012, 24, 23)

Wydaje się, że odnotować straty i zyski brzmi przesadnie poważnie, wprowadza nadmiernie podniosły styl i wysoką rangę, sugeruje nawiązanie do tematyki finansowej, a pojawia się $\mathrm{w}$ wywiadzie $\mathrm{z}$ trenerem piłkarskim, jest więc mało adekwatne:

Ale jak dotąd więcej odnotowuje pan strat niż zysków? (PN2012, 48, 14)

W poniższym przykładzie wykorzystano łączliwość czasownika nieść - zamiast pomagać i radzić wprowadzono konstrukcję nieść pomoc i radę, która pozwala bez posługiwania się dodatkowym komponentem jednoznacznie przekazać komunikat:

Z czasem mocno umalowane panie w okienkach zaczęły reagować na chcących nieść pomoc i radę rodaków jak na obcych. (PN2012, 24, 26)

Z kolei analityczne konstrukcje z komponentami czasownikowymi zaliczyć i zanotować oraz rzeczownikiem asysta są charakterystyczne dla stylu potocznego, w przekazie ustnym nie brakuje zwłaszcza pierwszej propozycji - połączenia zaliczyć asystę, np.

W 31 spotkaniach w Bundeslidze zdobył 13 bramek i zanotowal 11 asyst. (PN2012, 24, 43)

Zaliczył bowiem asystę i gola miesiąca, cztery razy trafił na Wembley. (PN2012, 49, 32)

Najpierw Szwed asystowal przy dwóch trafieniach kolegów, a w końcówce sam dwukrotnie wpakował piłkę do siatki. (PN2012, 48, 35)

Van Persie nie dość, że sam strzelił trzy gole, to jeszcze przy dwóch asystowal. (PN2012, 6, 42) 
Powyższa analiza potwierdza ustalenia Janusza Anusiewicza, Andrzeja Bogusławskiego i Wacława Cockiewicza, że do najczęściej pojawiających się podstaw konstrukcji analitycznych należą: dać, mieć, dokonać, prowadzić, udzielać [por. Anusiewicz 1978; Bogusławski 1978: 17-30; Cockiewicz 2000]. Zestaw ten można rozbudować jeszcze chociażby o nieść, odnotować, zanotować czy zaliczyć.

Kolejną grupę analitycznych struktur czasownikowych stanowią rozbudowane konstrukcje, które nie mają wspólnych morfemów z odpowiadającymi im czasownikami, ale przekazują treści synonimiczne. Różnica między syntetyzmem a wielowyrazowym ekwiwalentem sprowadza się przeważnie do zabarwienia stylistycznego.

Właściwość ta uwidacznia się zwłaszcza podczas opisywania momentu narodzin i śmierci. Zdarzenia te mogą zostać nazwane neutralnymi czasownikami naro$d z i c ́$, umrzeć, zginać, jednak w artykułach publikowanych w polskich tygodnikach niejednokrotnie przyjmują rozbudowaną formę, często o charakterze metaforycznym. Syntetyzm urodzić bywa zastępowany analitycznymi konstrukcjami czasownikowymi opuścić tono, przyjść na świat, być na świecie, które podkreślają wagę tego wydarzenia, a jednocześnie mogą zostać potraktowane w sposób dosłowny:

Tyle tygodni miała, kiedy opuścila lono. (P2012, 50, 27)

Tyle gramów będzie miał relikwiarz, projektowany na przyszłościową uroczystość kanonizacji papieża, odwzorowujący wagę Glorii, gdy przyszła na świat. (P2012, 50, 27)

Przed wyjazdową batalią ze Swansea City po razy ostatni na koncie Drozdów były cztery z rzędu wygrane, gdy większości graczy nie było jeszcze na świecie, a ich dzisiejszy opiekun zaczynał kopać piłkę w zespole juniorów szkockiego St Mirren. (PN2012, 49, 20)

Trochę inne konotacje przywołują struktury opisujące umieranie. Wiele z nich podkreśla, że życie jest najcenniejszą wartością. Patetyczny wymiar mają analityzmy stracić życie i ponieść śmierć, uwypuklają wagę tego, co się dokonało:

Był 1 lipca 2005 r., trzy miesiące wcześniej umarł Jan Paweł. (P2012, 50, 27)

Zginęło 25 osób, a 517 poważnie ucierpiało. (PN2012, 6, 5)

W wyniku pomeczowych zamieszek życie stracilo 318 osób, ponad 500 zostało rannych. (PN2012, 6, 5)

Warto przypomnieć kilka innych zdarzeń stadionowych, w wyniku których ludzie tracili życie. $(\mathrm{PN} 2012,6,5)$

Oficjalnie podano, że śmierć poniosło 61 osób, ale nikt w to nie wierzył. (PN2012, 6, 5)

Ogromny tumult sprawił, że śmierć poniosły 43 osoby, a dwa razy tyle zostało rannych. (PN2012, 6, 6)

Umieranie często objęte jest tabu językowym. Jak zauważa Anna Dąbrowska: myślenie magiczne zakłada, że nazwa jakiegoś zjawiska (choroby, zwierzęcia, śmierci, Boga itp.) posiada moc sprawczą i samo jej wymówienie przywołuje dane zjawisko do osoby, która niebacznie 
tę nazwę wymieniła. We współczesnych, tzw. cywilizowanych, społeczeństwach działanie tej przyczyny ogranicza się przede wszystkim do stosowania nazw zastępczych w odniesieniu do śmierci, groźnych chorób, nazw Boga i diabła. [Dąbrowska 1991: 165]

Badaczka podkreśla ponadto, że często przyczyną niemówienia o pewnych kwestiach wprost jest strach tkwiący głęboko w podświadomości człowieka, nierzadko także są to zagadnienia delikatne, więc ich unikanie jest oznaką dobrego wychowania [Dąbrowska 1991: 166]. Na pierwszy plan w takich orzeczeniach peryfrastycznych wysuwa się więc funkcja eufemizacyjna. Być daleko stąd i nie wrócić do domu łagodnie przekazują informację o śmierci, ich właściwe odczytanie uzależnione jest od kontekstu, np.

Kamera zaglądała w oczy roztańczonej Szaflarskiej, zatrzymywała się na Witoldzie Grucy, niegdyś wielkim tancerzu, na Irenie Kwiatkowskiej, która kilka miesięcy później będzie już daleko stąd, ale póki co głośno dowodzi, że diabła granego przez Nowickiego „wcale się nie przelękła, tylko strach zagrała", na Stefanie Burczyku, który podpisze pakt z diabłem, byle ostatni raz zagrać przed widzami. (P2012, 51-52, 129)

Do domu nie wrócilo 96 kibiców, w tym wiele dzieci. (PN2012, 6, 6)

Z kolei połączenie nie ma kogoś wśród żywych co prawda z jednej strony jasno przekazuje komunikat, ale $\mathrm{z}$ drugiej nie nazywa dosłownie, jest więc łatwiejsze do zaakceptowania niż syntetyczne umrzeć:

Nie ma już wśród żywych wojownika, sportowca o nieposkromionych ambicjach, Czarodzieja z narożnika, jak pisała o Nim prasa zagraniczna. (PN2012, 11, 4)

Metaforyczny charakter widoczny jest w zestawieniu czarować w innym, lepszym ze światów ${ }^{1}$ - określenie takie wzbudza w odbiorcach poczucie, że śmierć nie jest kresem, ale początkiem czegoś lepszego, pozwala więc ze spokojem przyjąć wiadomość o odejściu. Potwierdza to tezę Anny Engelking, że „duża grupa metaforycznych określeń śmierci opiera się na pojmowaniu jej jako zasadniczej przemiany życia, jako przejścia do rzeczywistości o innej jakości niż ta, którą postrzegamy zmysłowo" [Engelking 1984: 119]. Oto przykład:

Teraz Czarodziej z narożnika będzie czarowal już w innym, lepszym ze światów... (PN2012, $11,5)$

Ocaleć przyjęło także obrazową formę uniknąć spotkania z gilotyna, która wskazuje odbiorcom, w jaki sposób pozbawiano życia w dawnych czasach:

${ }^{1}$ Konstrukcja ta ma także swoje uzasadnienie w treści artykułu. Tekst dotyczy nagłej śmierci Włodzimierza Smolarka, zwanego „Czarodziejem z narożnika”, autor posłużył się więc również grą językową polegającą na wykorzystaniu wyrazów czarować i czarodziej składających się z takich samych morfemów. 
Moda na skomplikowane i ciężkie jak królewska władza peruki skończyła się razem z wybuchem rewolucji francuskiej, a możni, którzy uniknęli spotkania z gilotyną, nosili przez kolejne dziesięciolecia naturalne fryzury. (P2012, 51-52, 147)

Peryfrastyczne określenia przylgnęły nie tylko do czasowników opisujących tak ważne tematy jak początek i kres czyjegoś życia, bytu. Analityczne konstrukcje mogą być również wykorzystywane do nazwania bardziej prozaicznych czynności - jak chociażby schudną́ . Wielowyrazowe połączenia informują nas o skutkach diety - tracimy zatem kilogramy, a obwód naszego pasa maleje, np.

Większość ludzi zaczyna ćwiczyć, by schudnąć. (P2012, 51-52, 113)

Choć stracili niewiele kilogramów, to uczestnikom badań obniżyło się ciśnienie krwi i spowolnił rytm pracy serca, wzrosła wydolność, poprawił nastrój, a obwód pasa zmalal. (P 2012, $51-52,113)$

Najważniejszym elementem widowiska piłkarskiego jest dla wielu kibiców i zawodników strzelenie bramki. Dziennikarze wypracowali szereg określeń, by niekonwencjonalnie nazwać tę właśnie część meczu. I tak można po prostu syntetycznie napisać, że ktoś strzelit ${ }^{2}$ czy trafit - nawet bez podania dopełnienia (bramka, gol) taki przekaz jest dla odbiorców zrozumiały, choć oczywiście pojawiają się i doprecyzowane w ten sposób informacje (zdobyć bramkę, strzelić gola czy nacechowane potocznością wbić gola):

Niby mamy przewagę, prowadzimy grę i posiadamy piłkę, ale jednak nie strzelamy i nie wygrywamy. (PN2012, 49, 14)

Z Krywbasem trafiliśmy już na początku spotkania i skończyło się naszą wygraną 6:0. (PN2012, 48, 20)

Kaczmarek oddał mu futbolówkę, a Stępiński ośmieszył w szesnastce Piotra Malarczyka i pewnym uderzeniem zdobył bramkę. (PN2012, 49, 40)

Cesc strzelił dwa gole i zakończył w ten sposób ośmiomiesięczną passę bez zdobyczy bramkowej - poprzednio strzelił 8 lutego w pucharowym meczu z Valencią. (PN2012, 50, 21)

Isco zdobyl dwie bramki w LM, tak jak starszy od niego o ponad dekadę były reprezentant Hiszpanii Joaquin, zaś po jednym golu strzelili: Urugwajczyk Seba oraz Argentyńczycy: Diego Buonanotte i Javier Saviola. (PN2012, 50, 34)

W znakomitej formie jest Ałan Dzagojew, który Czechom wbil dwa gole. (PN2012, 24, 16)

Nierzadko analityczne zestawienia nazywają wprost wykonaną przez zawodników czynność: postać pitkę do bramki, skierować piłkę do siatki, trafić do siatki rywala, umieścić futbolówkę w siatce, trafić do bramki, umieścić piłkę

2 Trzeba zwrócić uwagę, że syntetyzm strzelić może odwoływać do dwóch analitycznych konstrukcji czasownikowych: oddać strzat i strzelić gola. By właściwie zinterpretować, niezbędne jest zapoznanie się z kontekstem. 
w bramce przeciwnika, wpakować piłkę do siatki - opisują one dokładnie, co gracze wykonali z piłką:

Wówczas to w ciągu 10 minut aż trzykrotnie posłal pilkę do bramki. (PN2012, 50, 2)

Magiera tym razem z akcji bardzo precyzyjnie zagrał w pole karne, gdzie największym refleksem wykazał się Wojciech Łuczak i uderzeniem nogą skierował piłkę do siatki tuż przy słupku bramki bezradnego Michała Buchalika. (PN2012, 50, 42)

Sześciokrotnie do siatki rywala trafial trzy lata starszy od niego inny napastnik mistrzów Lucas Pratto. (PN2012, 50, 38)

Mariusz Magiera dośrodkował z rzutu rożnego, a stojący koło bliższego słupka Mateusz Zahara sprytnym strzałem głową umieścil futbolówkę w siatce. (PN2012, 50, 42)

Cieniem na jego dokonaniach kładzie się jedynie fakt, że nie potrafił ani razu umieścić piłki w bramce przeciwnika w europejskich pucharach. (PN2012, 6, 10)

Po rzucie rożnym Reusa i niefortunnym zgraniu piłki przez Mario Mandżukicia do bramki monachijczyków trafil Goetze. (PN2012, 49, 35)

Najpierw Szwed asystował przy dwóch trafieniach kolegów, a w końcówce sam dwukrotnie wpakowal pilkę do siatki. (PN2012, 48, 35)

Wpisać się na listę strzelców, pokonać bramkarza rywali na pierwszym miejscu stawiają zaś wykonawcę, a nie to, czego on dokonuje z futbolówką, np.

Po raz pierwszy na listę strzelców w bieżącej edycji wpisał się 27-letni Fernando Llorente, ale po końcowym gwizdku Bielsa oświadczył, że mecz miał większe znaczenie dla wizerunku klubu niż w kwestii sportowej. (PN2012, 49, 3)

Już w poprzednim sezonie dziewiętnastokrotnie pokonywal bramkarza rywali, w obecnym, mimo że do zakończenia zasadniczej części rozgrywek jeszcze dziewięć kolejek, znacznie poprawił to osiągnięcie. (PN20126, 10)

Na uwagę zasługuje też metaforyczne określenie wjechać do bramki z piłka, które nawiązuje do stylu gry polegającego na wymienianiu niezliczonej liczby podań i strzelaniu do bramki z jak najbliższej odległości.

Wydawało się, że przyjęte przed meczem przez obu trenerów sposoby sforsowania defensywy rywali zawiodły, że Hiszpanie nie wjadą do bramki Włochów z piłką, a ci nie zaskoczą wysokich stoperów La Roja długimi, górnymi piłkami od napastników lub skrzydłowych, choć Pirlo zagrywał je niebywale dokładnie. (PN2012, 24, 31)

Zdobycie bramki wpływa na rezultat spotkania, a to właśnie informacja o końcowym wyniku jest kolejnym elementem, który może zostać opisany z wykorzystaniem analityzmów i syntetyzmów. Wygrać i przegrać to bezokoliczniki neutralne, ale już odnieść zwycięstwo, wyjść zwycięsko ${ }^{3}$, doznać porażki

${ }^{3}$ Jako ekwiwalenty analitycznych konstrukcji czasownikowych odnieść zwycięstwo, wyjść zwycięsko można potraktować także bezokolicznik zwyciężyć (np. Drużyny z Kraju Kawy zwyciężaly 
czy ponieść porażkę nie są obojętne stylistycznie, nadają wypowiedzi wzniosłości, służą wyolbrzymieniu przegranej lub gloryfikowaniu zwycięstwa [Burska 2014]:

Pod jego wodzą zespół wygral w Pampelunie pierwszy mecz wyjazdowy w tym sezonie ligowym. (PN2012, 50, 23) $50,47)$

Zespół Nawałki też ma charakter, przez całą jesień przegral tylko jedno spotkanie. (PN2012,

Bardzo ważne zwycięstwo odnieśli zawodnicy z Sochaux w ostatni weekend, zwłaszcza w kontekście walki o utrzymanie w Ligue 1. (PN2012, 11, 29)

Zwycięsko z tego dwumeczu wyszli nasi poludniowi sasiedzi, którzy odnotowali skromna wygrana i bezbramkowy remis. (PN2012, 50, 36)

Sześć dni później w Bielsku-Białej w 48 minucie meczu z Podbeskidziem z kolei rzut karny zmarnował Paweł Wszołek, ale potem znowu udało się zdobyć bramkę i poloniści odnieśli zwycięstwo 1:0. (PN2012, 48, 16)

Ten zespół w ósmym meczu pod wodzą Del Neriego doznal siódmej porażki, co niemalże przesądza o rychłej dymisji szkoleniowca. (PN2012, 50, 31)

Nieoczekiwanych porażek doznały dwie drużyny z Manchesteru, uznawane przez wielu fachowców za głównych kandydatów do udziału w tegorocznym wielkim finale LE. (PN2012, 11, 31)

I w tym sensie Wisła poniosła porażkę, skok na bank się nie powiódł. (PN2012, 15, 2)

Częstym zjawiskiem jest posługiwanie się komponentem punkt w celu oznajmienia rezultatu. Zabieg taki ma na celu eufemizację przekazywanych treści zamiast przegrać w tekstach obecne są formy gubić punkty i tracić punkty, które przez kibiców są odczytywane łagodniej niż ich jednowyrazowy odpowiednik, wyjątek może stanowić połączenie oddać punkty, które sugeruje, że drużyna poddała się bez walki, np.

Wisła w zastraszający sposób gubi punkty na własnym boisku i nie potrafi zdobywać bramek. (PN2012, 50, 8)

Należy jednak pamiętać, że zespół Szachtara u siebie nie lubi tracić punktów. (PN2012, 49, 2)

Z kolei ta znalazła wreszcie ligowego pogromcę - oddała punkty Jagiellonii, dla której zwycięstwo przy Łazienkowskiej było jednak jedynym w analizowanym okresie. (PN2012, 49, 40)

Analogicznie zremisować to podzielić się punktami, wygrać zaś to sięgnać po trzy punkty lub zainkasować komplet punktów. Ostatnia forma wykazuje duże nacechowanie potocznością:

Myślałem, że w meczu Śląska Wrocław z Legią Warszawa drużyny podzielą się punktami. (PN2012, 50, 41)

także $w$ dwóch pierwszych edycjach po reaktywacji klubowego mundialu w 2005 i 2006 roku (PN2012, 49, 22), a nie wygrać. Wówczas należałoby je zaliczyć do poprzedniej grupy - struktur werbo-nominalnych, w których widoczne jest pokrewieństwo morfologiczne z jednoelementowym czasownikiem im odpowiadającym. 
Grający w dziewięciu gospodarze zdołali jednak utrzymać skromne prowadzenie i sięgnęli po ważne trzy punkty. (PN2012, 11, 28)

Pozostające wiosną bez wygranych - gdańska Lechia i Łódzki KS - w minionej kolejce wreszcie zainkasowały komplety punktów. (PN2012, 14, 47)

Na uwage zasługuje jeszcze jedno metaforyczne, a zarazem eufemistyczne określenie - przegrać definiowane jako dostać od rywali lekcję futbolu. Odwołuje się ono do przestrzeni szkolnej i relacji uczeń-nauczyciel, wywyższa przeciwników, nie przekazuje jednak zaś żadnej negatywnej informacji na temat postawy przegranej drużyny, np.

Dziś łatwiej jest wygrać mecz, a wtedy prezentując zbyt ofensywną grę, łatwiej było otrzymać od rywali lekcję futbolu. (PN2012, 48, 15)

W języku sportowym pojawia się wiele synonimicznych określeń nie tylko w celu nazwania zdarzeń na boisku, ale także zachowań piłkarzy, trenerów czy działaczy. Jednoelementowe zejść może zostać zastąpione przenośnym powędrować do zajezdni, które bardzo dobrze wyraża decyzję szkoleniowca o chwilowej nieprzydatności zawodnika i zdjęciu go z boiska:

I po chwili Iniesta spudłował minimalnie, a po minucie Balotelli najpierw zabrał piłkę ostrzyżonemu specjalnie na turniej na krótko Sergio Ramosowi, a potem dał mu się ośmieszyć i powędrował do zajezdni decyzją trenera. (PN2012, 24, 31)

By poinformować o całkowitej nieprzydatności trenera, używa się analitycznej formy pokazać komuś drzwi, która - choć przekazuje mało optymistyczne treści - jest łagodniejsza od syntetycznego wyrzucić, np.

Mistrz świata z Brazylią miał nawet udany start, ale nie potrafił się dogadać z większością graczy w szatni i po siedmiu miesiącach pokazano mu drzwi. (PN2012, 11, 17)

Kiedy przestał strzelać gole, pozycja Beniteza zaczęła się chwiać, aż w końcu też pokazano mu drzwi na Anfield. (PN2012, 48, 23)

Odwrotną sytuację, czyli to, że ktoś jest trenerem danej drużyny, można przekazać za pomocą jednowyrazowego trenować, ale można także posłużyć się metaforyczną, rozbudowaną formą zasiadać za sterami, która podkreśla, że szkoleniowiec odgrywa niebagatelną rolę i w dużej mierze od niego zależą wyniki zespołu:

Tak było, gdy zasiadal za sterami Interu Mediolan, tak jest obecnie, kiedy prowadzi Manchester City. (PN2012, 50, 11)

Analitycznych konstrukcji czasownikowych doczekały się także czynności związane z poszczególnymi formacjami na boisku. Bronić bywa stosowane wymiennie ze stać między stupkami - akcentującym miejsce przebywania bramkarza - oraz petnić straż - przypisującym golkiperowi odpowiedzialną funkcję i jednocześnie patetycznie podkreślającym jego rangę: 
I bronil znakomicie. (PN2012, 6, 38)

W zespole Kogutów broni bowiem wiekowy Amerykanin Brad Friedel, a sir Alex Ferguson nie jest zadowolony ani z postawy Davida de Gei, ani Andersa Lindegaarda. (PN2012, 6, 29)

I wydaje się, że w rundzie rewanżowej, przynajmniej na razie, to Szwed będzie stal między słupkami PSV. (PN2012, 6, 24)

W Copa del Rey grał Jose Manuel Pinto, Valdes pełnil straż w lidze. (PN2012, 6, 38)

Powołać i zagościć w notesie selekcjonera tworzą parę synonimicznych określeń nazywających czynność wykonywaną przez trenera reprezentacji narodowej. Syntetyzm skupia się na nadawcy, analityzm zaś na odbiorcy:

I trzeba przyznać, że dobrze odrobił pracę domową - powołal naprawdę wyróżniających się zawodników w końcówce roku. (PN2012, 50, 42)

Większość wybrańców trenera Fornalika powołania słusznie traktuje jako przedświąteczny prezent, z którego warto skorzystać, by na dłużej zagościć w notesie selekcjonera. (PN2012, 50, 43)

Wywalczyć promocję - w przeciwieństwie do jednowyrazowego awansować - podkreśla, że sukces nie przyszedł łatwo, tym bardziej więc trzeba go cenić, np.

Nie powiem, że musimy awansować, bo znanych jest wiele przypadków, gdy jakiś team mocno się spinał, a kończyło się to katastrofą. (PN2012, 6, 45)

Wywalczyć promocję możemy, najważniejsze jednak, by przygoda z ekstraklasą, gdy do niej trafimy, trwała dłużej niż sezon - mówi Dudek. (PN2012, 6, 45)

Bywa, iż dziennikarze są świadomi, że istnieje moda na używanie określonych analitycznych konstrukcji czasownikowych w miejsce ich jednoelementowych ekwiwalentów. Za pomocą sformułowania jak to się ostatnio mówi zostaje wyrażona ironia wobec stali się największymi beneficjentami wprowadzonego zamiast synonimicznego skorzystali:

Ale to oni najbardziej na całym zamieszaniu skorzystali; jak to się ostatnio mówi: stali się największymi beneficjentami. (PN2012, 11, 18)

W artykułach ukazujących się w „Polityce” i „Piłce Nożnej” często pojawiają się związki frazeologiczne - wszak posługiwanie się spetryfikowanymi połączeniami wyrazowymi świadczy nie tylko o erudycji dziennikarza, ale także aktywizuje czytelników. Również wśród frazeologizmów liczną grupę stanowią te, które da się zastąpić syntetycznym czasownikiem ${ }^{4}$.

Bezokolicznik pomagać jest $\mathrm{w}$ tygodnikach stosowany wymiennie z połączeniami wyciagnać do kogoś rękę i wyciagnać pomocna dtoń - podać komuś, wyciagnać do kogoś (pomocna, przyjazna) rękę, dłoń, podn. bratnia dłoń a) 'oka-

\footnotetext{
${ }^{4}$ O różnicach między predykacją peryfrastyczną a frazeologizmami zob. I. Loewe 2000: 20-23.
} 
zać komuś życzliwość, chęć pomocy', b) 'pomóc komuś' [WSF: 4415] - które uwypuklają szlachetne intencje niosących wsparcie, np.

Wtedy rękę do Dołęgi wyciągnąl biznesmen z Otwocka, Stefan Maciejewski, za młodu sztangista. (P2012, 51-52, 152)

Odradzająca się Borussia to także zasługa Bayernu, którego władze po finansowym tąpnięciu, spowodowanym wejściem na giełdę, wyciągnęły pomocną dłoń i pożyczyły konkurentowi pieniądze. (PN2012, 48, 31)

Jeśli chodzi o mnie, nie miałem innych propozycji, a działacze Kolejarza wyciągnęli do mnie rękę, za co jestem im wdzięczny. (PN2012, 48, 42)

Frazeologizm bywa wprowadzany w celach eufemizacyjnych - tak dzieje się w przypadku mijać się z prawda - euf. mijać się, rozmijać z prawda 'mówić nieprawdę; kłamać' [WSF: 396]. To stałe połączenie wyrazowe ma zdecydowanie łagodniejszy wydźwięk niż odpowiadające mu kłamać, które wprost i bez żadnych dwuznaczności nazywa nieuczciwe postępowanie, np.

Jestem przekonany, że większość tych respondentów kłamala. (P2012, 50, 36)

Precedensem jest przypadek Guardioli, który w 2010 roku za stwierdzenie, iż sędzia Clos Gomez kłamie i wie o tym, został trzy miesiące później ukarany finansowo. (PN2012, 11, 2-3)

Zresztą w meczach reprezentacji nie zawodziłem, to najlepszy dowód, że nie mijam się z prawdą. (PN2012, 6, 28)

W zgromadzonym materiale kilkukrotnie pojawiło się wielowyrazowe sformułowanie spuścić z tonu - spuścić z tonu, spuścić uszy po sobie 'zmniejszyć swoje wymagania, spokornieć' [WSF: 506] - w odniesieniu do zmiany charakteru ludzi najtrafniejszym odpowiednikiem wydaje się spokornieć, z kolei by opisać gorszą niż zwykle dyspozycję zawodników czy sytuację klubu, można zastąpić ten frazeologizm bezokolicznikiem ostabnaćc:

Konserwatysta - realista, który gromko sprzeciwił się Unii, ale potem, po cichu, spuścil z tonu. (P2012, 50, 16)

Wydawało się, że zespół z takim potencjałem ludzkim, a także zapleczem w postaci stadionu, kibiców i bogatego właściciela, nie może tak bardzo spuścić z tonu. (PN2012, 50, 47)

Jeszcze po zakończeniu poprzedniego sezonu uznawany za bezdyskusyjnie najlepszego na tej pozycji gracza na świecie Hiszpan, dziś już ten status utracił: nie dlatego, iż spuścil z tonu, lecz ponieważ inni też otrzymali szansę zaprezentowania walorów i ją wykorzystali. (PN2012, 11, 19)

Dla wyrażenia przeciwnych treści stosowany jest inny związek frazeologiczny z komponentem ton - nadawać ton czemuś 'wywierać wpływ na charakter lub

${ }^{5}$ Wszelkie objaśnienia związków frazeologicznych pochodzą z Wielkiego słownika frazeologicznego PWN z przysłowiami (skrót: WSF), oprac. A. Kłosińska, E. Sobol, A. Stankiewicz, Wydawnictwo Naukowe PWN, Warszawa 2009, po dwukropku podano numer strony. 
wygląd czegoś; także: przewodzić, dominować gdzieś’ [WSF: 561]. Jednowyrazowym ekwiwalentem najlepiej oddającym to połączenie jest dominować, które dobitniej uwypukla czyjąś przewagę, np.

Cracovia i Zawisza Bydgoszcz - te kluby od początku sezonu miały nadawać ton pierwszoligowym rozgrywkom. (PN2012, 49, 44)

Mimo tych przeciwności drużyna nadaje ton w rozgrywkach Ligue 1, a awans do pucharowej fazy Ligi Europy zapewniła sobie w imponującym stylu już po pierwszych czterech zwycięstwach. (PN2012, 50, 28)

Dla zobrazowania dominacji można posłużyć się także innymi trwałymi połączeniami wyrazowymi mającymi syntetyczne odpowiedniki. Bić na głowę to inaczej górować lub dominować, roznieść w pyt-rozgromić, zapędzić w kozi róg - zakasować, mieć w garści natomiast w przytoczonym przykładzie najprecyzyjniej odzwierciedlałoby wygrać. Dwa pierwsze frazeologizmy znacznie bardziej uwypuklają przewagę, a co za tym idzie - mają większy wpływ na odbiorcę:

Przecież nawet pod względem organizacyjnym jest to firma, która bije wszystkie moje poprzednie kluby na glowę (PN2012, 11, 23); bić, pobić kogoś, coś na głowe a) 'znacznie przewyższać, przewyższyć kogoś, coś pod jakimś względem, górować nad kimś, nad czymś’' b) 'zwyciężać, pokonywać kogoś w rywalizacji, w walce, zadawać komuś druzgocącą klęskę’. [WSF: 113]

Pod względem oczytania i sprawności językowej Korwin-Mikke bije na głowę większość współczesnych polityków. (P2012, 50, 19)

W tym turnieju nie ma słabych i słabszych, walczyć trzeba do końca ze wszystkimi, nawet z Rosjanami, którzy roznieśli Czechów w pyl (PN2012, 24, 47); zetrzeć, zamienić, roznieść itp. coś w pyt 'całkowicie zniszczyć, unicestwić coś'. [WSF: 431]

Dlatego po gwizdku kończącym pierwszą część spotkania wszystko wskazywało na to, że mamy mecz w garści (PN2012, 24, 7); mieć, trzymać kogoś, coś w garści 'uzależnić kogoś lub coś od siebie, kierować, rządzić kimś lub czymś’. [WSF: 108]

Według zgodnych opinii fachowców przeciwnik z Ukrainy był do przejścia, ale w drugiej odsłonie meczu wybrańcy Saschy Lewandowskiego dwukrotnie dali się zapędzić w kozi róg i... przegrali [PN2012, 48, 34); zapędzić kogoś w kozi róg 'wykazać swoją zdecydowaną przewagę nad kimś, zakasować kogoś'. [WSF: 453]

O dominacji - ale w sferze uczuć - mówi też analityczna konstrukcja czasownikowa coś bierze nad kimś, nad czymś górę, jednoznacznie wskazuje ona, że w niektórych momentach stany psychiczne mogą dominować nad racjonalnym postrzeganiem rzeczywistości i kierować poczynaniami człowieka:

Takie spędzanie świąt może się wydawać sensowne tym osobom, które wiedzą, że przy wigilijnym stole górę wezmą emocje, uprzedzenia - i że to może je bardzo dużo kosztować (P2012, 51-52, 22); coś bierze nad kimś, nad czymś górę 'o poglądach, stanach psychicznych, uczuciach: dominować, kierować czyimś postępowaniem'. [WSF: 126] 
Połączenie nie mieć co do garnka włożyć dobitnie odzwierciedla zły stan materialny bohatera artykułu, jednak wydaje się, że nazywający bezpośrednio zaistniałą sytuację syntetyzm głodować ma silniejszą wymowę:

- Gdyby nie istniał, na Święta nie miałbym co do garnka włożyć. (P2012, 51-52, 6); nie mieć, nie ma co do garnka włożyć, do ust (w usta), pot. do gęby (w gębę), posp. do pyska włożyć 'nie mieć, nie ma nic do jedzenia, głodować'. [WSF: 624]

Frazeologizmy często używane są do wyrażenia postawy wobec zaistniałej sytuacji czy opisania stanów emocjonalnych. Zamiast przeciwstawić dziennikarze używają stawić czoło, przeciwną sytuację opisuje para zrezygnować - machnać ręka. Pozytywne odczucia obrazują analityzm zacierać ręce i syntetyzm radować, negatywne zaś - psuć krew i zdenerwować. Wpływ wywierany na psychikę oddają natomiast wziąć do serca i przejmować:

Siła archetypowych potrzeb w nas jest tak silna, że stawiamy czoło (P2012, 51-52, 22); stawić czoło (czoła) komuś, czemuś 'oprzeć się, przeciwstawić się komuś, czemuś, podjąć walkę z kimś, z czymś'. [WSF: 56]

Człowiek zaczyna dostrzegać paradoksy - i nie macha ręką, tylko szuka wspólnego mianownika oraz jest w stanie go znaleźć (P2012, 51-52, 24); machnać na kogoś, na coś ręka a) 'zrezygnować z kogoś, z czegoś, uznać coś za stracone', b) 'zlekceważyć kogoś, coś, przestać zwracać na kogoś, na coś uwagę'. [WSF: 229]

Trzeźwo patrzący zacierali jednak ręce (PN2012, 50, 17); zacierać ręce a) 'trzeć dłonią o dłoń z zimna albo na znak zadowolenia'; b) 'okazywać zadowolenie, radość; cieszyć się’. [WSF: 662]

I je znalazł - z pożytkiem dla WBA, klubu niezaliczanego do potentatów, ale umiejącego pod batutą Szkota psuć krew tym, którzy opływają w luksusy (PN2012, 49, 20); psuć sobie, komuś krew, napsuć sobie, komuś krwi 'wprawiać, wprawić siebie, kogoś w zły humor, denerwować, zdenerwować się (kogoś) czymś, irytować się, zirytować się czymś’. [WSF: 190]

Jednak zdaniem Wengera jego chłopcy wzięli sobie do serca mocno krytyczne uwagi, zwłaszcza kibiców i efekty przeszły oczekiwania (PN2012, 6, 42); brać, wziać (sobie) coś do serca 'przejmować się, przejąć się czymś, silnie odczuwać, odczuć coś'. [WSF: 467]

Do sfery dalekiej od rzeczywistości nawiązuje stały związek wyrazowy bujać w obłokach, któremu odpowiada synonimiczne marzyć. Wielowyrazowe określenie zdecydowanie bardziej podkreśla nierealność podjętych działań:

Do rozwiązania pozostaje natomiast zagadka - jak długo Markiewicz i jego drużyna będą bujać w obłokach (PN2012, 48, 34); bujać w obłokach 'być dalekim od realnego życia; także: być pogrążonym w marzeniach, marzyć' [WFS: 27]

Zdarza się, że związek frazeologiczny ma wyraźne nacechowanie potoczne, a to jego ekwiwalent nadaje się do zastosowania w komunikacji oficjalnej - tak dzieje się m.in. w synonimicznych parach wystrychnąć na dudka i ośmieszyć, wieszać na kimś psy i oczerniać, pluć sobie w brodę i żałować, miewać muchy w nosie i grymasić czy dać plamę i skompromitować: 
Tylko 19 lat i na koncie występy zarówno w Manchesterze United, jak i Juventusie, który podkradł (dla poprawy stosunków stanęło na milionie odstępnego) Anglikom Francuza mniej więcej tak, jak oni wcześniej wystrychnęli na dudka Le Havre (PN2012, 50, 31); pot. wystrychnąć kogoś na dudka 'oszukać kogoś, zrobić z kogoś głupca, ośmieszyć kogoś'. [WSF: 86]

Llorente zapewne pluje sobie $\mathbf{w}$ brodę, że nie zwolnił Pellegrino wcześniej i nie zatrudnił Rafy Beniteza, kiedy ten był jeszcze do wzięcia (PN2012, 49, 34); pot. pluć sobie w brodę 'wyrzucać sobie coś, żałować utraconej szansy, okazji'. [WSF: 362]

Jak zwykle przy okazji wielkich piłkarskich turniejów, staram się przygladać i analizować pracę drużyny, na której najchętniej wiesza się psy (PN2012, 24, 40); pot. wieszać psy na kimś 'obmawiać, oczerniać, szkalować kogoś'. [WSF: 356]

Balotelli to napastnik, który miewa muchy w nosie, posadzenie go w takim momencie na ławce rezerwowych spowodowałoby, że zawodnik byłby kompletnie nieprzydatny do końca turnieju (PN2012, 24, 22); pot. ktoś ma muchy w nosie; mucha komuś usiadła na nos; mucha kogoś ugryzła, ukąsiła 'ktoś grymasi, kaprysi, złości się i dąsa bez powodu'. [WSF: 259]

Podopiecznych trenera Vitora Pereiry czeka jednak trudne zadanie, aby prześcignąć Orły z Lizbony, a także nie dać plamy w Lidze Europy z Manchesterem City (PN2012, 6, 31); pot. dać plame 'skompromitować się'. [WSF: 361]

Dwukrotnie zaobserwowano sformułowanie coś jest komuś na rękę 'coś komuś odpowiada, jest dogodne dla kogoś' [WSF: 439], które bywa zastępowane syntetycznym czasownikiem odpowiadać. Wprowadzenie analitycznej konstrukcji czasownikowej charakterystycznej dla swobodnej mowy czyni tekst bardziej przystępnym:

Faktycznie, choć pewien jestem, że nie wszystkim jest to na rękę. (PN2012, 11, 12)

Rosjanom to było na rękę, bo sami planowali ściągnąć rywali do środka boiska, by na bokach najlepsi w zespole Advocaata: Arszawin i Dzagojew mieli jak najwięcej miejsca, byli pilnowani bez podwajania. (PN2012, 24, 18)

Patos ujawnia się z kolei w spetryfikowanych połączeniach: zabrać głos używanym zamiast przemówić, dojść do głosu pojawiającym się w miejsce ujawnić oraz wyjść na jaw, czyli okazać. Związki te nadają wypowiedzi wzniosłości i podkreślają rangę wykonawców czynności (w przypadku zabrać głos i dojść do głosu) lub zdarzeń (w przypadku wyjść na jaw), np.

Prezydent UEFA Michel Platini zabral głos w tej sprawie, zapowiadając przerywanie meczów w przypadku jakichkolwiek zachowań rasistowskich ze strony kibiców (PN2012, 24, 40); zabrać głos 'zacząć mówić; przemówić, wypowiedzieć się'. [WSF: 112]

Kiedy wyszlo na jaw, że wcale tak nie jest, wybuchła panika (P2012, 50, 44); wyjść na jaw 'stać się wiadomym, znanym; okazać się'. [WSF: 149]

Obie reprezentacje prezentują zbliżony poziom, u nas i u Czechów coraz mocniej do glosu dochodzą młodsi piłkarze (PN2012, 6, 15); dojść do głosu 'ujawnić się'. [WSF: 73]

Warto przyjrzeć się frazeologizmom z komponentem czasownikowym mieć. W mieć się na baczności przekaz jest skoncentrowany na podmiocie, najtrafniej 
zastąpić to połączenie syntetyzmem uważać. Do interpretacji sformułowania mieć na oku niezbędny jest kontekst. Z kilku możliwości najbliższy temu frazeologizmowi w analizowanym zdaniu jest czasownik obserwować:

Robert Lewandowski, który wygrał rywalizację z Barriosem, wykorzystując jego problemy ze zdrowiem, musi więc mieć się na baczności (PN2012, 6, 41); mieć się na baczności (przed kimś, przed czymś) 'być czujnym, ostrożnym w stosunku do kogoś, czegoś; uważać'. [WSF: 9]

Włoski szkoleniowiec już na jesieni ubiegłego roku wspominał, że tego chłopaka ma na oku (PN2012, 6, 33); mieć kogoś, coś na oku a) 'obserwować kogoś, coś, być ostrożnym, czujnym w stosunku do kogoś’, b) ‘strzec, pilnować kogoś, czegoś, czuwać nad kimś'. [WSF: 315]

Używanie jednoelementowych ekwiwalentów związków frazeologicznych wynika czasem z norm językowych. Połączenie mieć miejsce 'dziać się, odbywać się, zdarzać się, zachodzić' [WSF: 245] - mimo iż często pojawia się na łamach polskich tygodników - jest traktowane przez wydawnictwa poprawnościowe jako nadużywane w stylu publicystycznym, normatywiści zachęcają do posługiwania się syntetycznymi formami zdarzyć, odbyć czy zachodzić [SPP 2002: 441], np.

Ta druga sytuacja miała miejsce pięć metrów od pomocniczego asystenta pracującego za bramką. (PN2012, 24, 41)

Podobnie jak miało to miejsce w minionym sezonie, każda kolejka ligowa rozciągnięta będzie na cztery dni (potrwa od piątku do poniedziałku). (PN2012, 24, 44)

Przeprowadzona analiza pokazuje, że wszystkie trzy rodzaje analitycznych konstrukcji czasownikowych posiadających syntetyczne odpowiedniki są chętnie wykorzystywane we współczesnych polskich tygodnikach. Nie brakuje kolokacji werbo-nominalnych zawierających wspólne morfemy z odpowiadającymi im syntetyzmami leksykalnymi, jak również wszelkich innych wieloskładnikowych określeń (w tym spetryfikowanych związków wyrazowych) mających jednoelementowy ekwiwalent czasownikowy tożsamy lub bliski znaczeniowo. Różnica między analityzmem i syntetyzmem uwidacznia się zwłaszcza w zabarwieniu stylistycznym. Najczęściej nacechowane jest wielowyrazowe określenie - może ono być wykładnikiem potoczności albo wręcz przeciwnie - wprowadzać wysoki ton i dodawać wypowiedzi patosu, z kolei jego odpowiednik ma neutralny wydźwięk. Nierzadko analityczne konstrukcje czasownikowe mają za zadanie łagodzić przekazywane treści, co dzieje się zwłaszcza wówczas, gdy poruszane są tematy drażliwe, delikatne lub wypowiadający się nie chce ujawnić bezpośrednio swojego stanowiska. Jak twierdzi Iwona Loewe, ,predykacja peryfrastyczna dystansuje nadawce wobec treści i jest wyrazem wyrazistości i precyzji w języku” [Loewe 2010: 184].

Bywa, że posługiwanie się synonimicznymi formami o zróżnicowanej liczbie słów spowodowane jest względami normatywnymi i praktycznymi. Publikujący wiedzą, że wprowadzenie konkretnych konstrukcji jest modne i pozwoli im zyskać przychylność czytelników. Nie zawsze znalezienie równoważnika jest prostym zadaniem, a odbiorca musi zadać sobie trud, by trafnie odczytać przekaz, 
z pomocą przychodzi wówczas kontekst. Wielowyrazowe konstrukcje mogą służyć wartościowaniu - precyzyjniej wyrażają pozytywne bądź negatywne treści. Posługiwanie się analityzmami i syntetyzmami może mieć także praktyczne cele - pozwala uniknąć powtórzeń, zdobi przekaz. Warto też podkreślić, że czasem istnieją semantyczne różnice między analitycznymi konstrukcjami czasownikowymi i ich ekwiwalentami, na co uwagę zwrócił już A. Bogusławski:

ogląd regularnych orzeczeń peryfrastycznych każe przyjąć, że odznaczają się one swoistymi cechami semantycznymi, które nie pozwalają na ich dowolną wymianę z orzeczeniami prostymi. To prawda, że w wielkiej liczbie wypadków wymianie takiej nie odpowiadają różnice w obiektywnych stanach rzeczy. Nie można jednak odmówić orzeczeniom peryfrastycznym reprezentowania szczególnych komponentów semantycznych, które w określonych kontekstach mogą różnicować sytuacje w sposób całkiem zasadniczy. [Bogusławski 1978: 29]

Użytkownicy powinni być tego świadomi, by budując tekst, wybrać taką strukturę, która jak najlepiej odda zamierzony sens wypowiedzi.

\section{Bibliografia}

Anusiewicz J. [1978], Konstrukcje analityczne we wspótczesnym języku polskim, Ossolineum, Wrocław.

Bogusławski A. [1978], Jednostki języka a produkty językowe. Problem tzw. orzeczeń peryfrastycznych, [w:] Z zagadnień stownictwa współczesnego języka polskiego, Ossolineum, Wrocław.

Burska K. [2014], O analityzmach i syntetyzmach leksykalnych w publicystyce sportowej - na przykładzie peryfraz i uniwerbizmów, [w:] A. Garcarek-Sikorska, M. Kocot, K. Szafraniec (red.), Języki popkultury, Wydawnictwo Uniwersytetu Łódzkiego, Łódź.

Cockiewicz W. [2000], Konstrukcje analityczne w języku polskiej telewizji w latach siedemdziesiątych $i$ dziś, [w:] J. Bralczyk, K. Mosiołek-Kłosińska (red.), Język w mediach masowych, Upowszechnianie Nauki - Oświata „UN-O”, Warszawa.

Dąbrowska A. [1991], Eufemizmy życia codziennego. Zarys problematyki na materiale polskiej powieści kryminalnej, [w:] J. Puzynina, J. Bartmiński (red.), Język a kultura, t. 2: Zagadnienia leksykalne i aksjologiczne, Wiedza o Kulturze, Wrocław.

Engelking A. [1984], Istota i ewolucja eufemizmów (na przykladzie zastępczych określeń śmierci), „Przegląd Humanistyczny”, nr 4.

Hodalska M. [2010], Mocarz Ducha zamieszkat w niebie. Peryfrazy ornamentacyjne i eufemizacyjne w prasie, ,Język Polski”, z. 4-5.

Loewe I. [2000], Konstrukcje analityczne w poezji Młodej Polski, Wydawnictwo Uniwersytetu Śląskiego, Katowice.

Loewe I. [2010], Konstrukcje analityczne w polskiej telewizji na progu drugiej dekady XXI wieku, „Stylistyka”, XIX.

Stownik poprawnej polszczyzny [2002], A. Markowski (red.), Wydawnictwo Naukowe PWN, Warszawa.

Vetulani G. [2001], Kolokacje werbo-nominalne jako odrębne jednostki języka i ich zastosowanie, [w:] E. Jędrzejko (red.), W kręgu języka polskiego. Śląsko-poznańskie kolokwia lingwistyczne, Wydawnictwo Uniwersytetu Śląskiego, Katowice.

Wielki słownik frazeologiczny PWN z przysłowiami [2009], A. Kłosińska, E. Sobol, A. Stankiewicz (oprac.), Wydawnictwo Naukowe PWN, Warszawa. 